\title{
Improved Control of Postharvest Decay of Pears by the Combination of Candida sake (CPA-1) and Ammonium Molybdate
}

\author{
Carla Nunes, Josep Usall, Neus Teixidó, Maribel Abadias, and Immaculada Viñas
}

Postharvest Unit, CeRTA, Centre UdL-IRTA, 177 Rovira Roure Avenue, 25198 Lleida, Catalonia, Spain. Accepted for publication 1 November 2001

\section{ABSTRACT}

Nunes, C., Usall, J., Teixidó, N., Abadias, M., and Viñas, I. 2002. Improved control of postharvest decay of pears by the combination of Candida sake (CPA-1) and ammonium molybdate. Phytopathology 92: 281-287.

The potential enhancement of Candida sake (CPA-1) by ammonium molybdate to control blue and gray mold caused by Penicillium expansum and Botrytis cinerea, respectively, on Blanquilla pears was investigated. In laboratory trials, improved control of blue and gray molds was obtained with the application of ammonium molybdate $(1,5,10$, and $15 \mathrm{mM})$ alone or in combination with C. sake at $2 \times 10^{6}$ or $2 \times 10^{7} \mathrm{CFU} \mathrm{ml}{ }^{-1}$ on Blanquilla pears stored at $20^{\circ} \mathrm{C}$. In semicommercial trials at $1{ }^{\circ} \mathrm{C}$ for
5 months, the efficacy of $C$. sake at $2 \times 10^{6} \mathrm{CFU} \mathrm{ml}^{-1}$ on reducing $P$. expansum and $B$. cinerea decay was enhanced more than $88 \%$ with the addition of ammonium molybdate $5 \mathrm{mM}$ in the 1999-2000 season. In two seasons, the performance $C$. sake at $2 \times 10^{6} \mathrm{CFU} \mathrm{ml}{ }^{-1}$ plus ammonium molybdate was similar to or greater than that of $C$. sake at $2 \times 10^{7} \mathrm{CFU} \mathrm{ml}{ }^{-1}$. Similar control of blue mold was obtained on pears stored under low oxygen conditions. The preharvest application of ammonium molybdate did not reduce postharvest blue mold decay. The population of $C$. sake on pear wounds significantly decreased in the presence of ammonium molybdate 1 and $5 \mathrm{mM}$ at 20 and $1^{\circ} \mathrm{C}$.

Additional keywords: nutritional enhancement, storage.
Synthetic fungicides are the primary means of controlling postharvest diseases, but concerns about the presence of chemical residues in food, the development of fungicide-resistant strains of postharvest pathogens, and the deregistration of some fungicides have generated interest in the development of alternative methods $(9,32)$.

Biological control has been extensively studied in recent years and the use of yeasts and bacteria as antagonists has been reported to control many postharvest diseases of fruit $(4,12,14,19,22,29)$. Although the use of biocontrol agents has been successful, their successful commercialization will depend on whether they are capable of effectively controlling decay of fruit from different locations and different cultivars.

Microorganisms as biocontrol agents have a relatively narrow spectrum of activity when compared with chemical fungicides (13). Greater and broader activity can be achieved by applying higher concentrations of the antagonist $(8,20)$, but increasing the antagonist populations makes biological control less economical. Biological control of postharvest diseases is complex and involves a number of variables, such as biological and environmental factors $(1,17,31)$. The chemical environment can be manipulated to enhance biocontrol activity of the antagonist and, in fact, several works report additives that enhance the effectiveness of microbial antagonists $(3,9,11,16,33)$.

Preliminary assays in vitro and in vivo (18) on the combination of some nutrients with Candida sake strain CPA-1 in order to enhance biological control showed that the combination of the antagonist and ammonium molybdate reduced blue mold decay caused by Penicillium expansum on apples and pears more than other chemicals. However, the ability of ammonium molybdate to control disease development has not been fully explored.

Corresponding author: C. Nunes; E-mail address: nunes.carla@mail.telepac.pt

Publication no. P-2002-0115-01R

(c) 2002 The American Phytopathological Society
Ammonium molybdate affects metabolic processes in several organisms $(2,6,30)$. The basis of its biological activity was reported to be its ability to inhibit acid phosphatase, which interferes with phosphorylation and dephosphorylation (5), one of the most important processes of cell regulating $(7,21)$.

The current study was undertaken to (i) determine the potential of ammonium molybdate to enhance biological control of $P$. expansum and Botrytis cinerea decay on pears with the yeast $C$. sake (CPA-1) under different storage conditions, (ii) compare the efficacy of preharvest and postharvest application of ammonium molybdate to control $P$. expansum decay of pears during cold storage, and (iii) determine the effect of ammonium molybdate on the population dynamics of $C$. sake in pear wounds.

\section{MATERIALS AND METHODS}

Yeast isolate and pathogens. The isolate used in this study, $C$. sake (Saito \& Ota) van Uden and Buckley strain CPA-1 from UdL-IRTA (Spain), was isolated from the surface of an apple. This strain demonstrated antagonistic activity against $P$. expansum Link and B. cinerea Pers. in pome fruit (29). It is deposited in Colección Española de Cultivos Tipo, CECT-10817 (Universidad de Valencia, Campus de Burjasot, Burjasot, Valencia, Spain). Yeast cells were prepared by growing cultures in nutrient yeast dextrose broth (NYDB: nutrient broth, $8 \mathrm{~g} \mathrm{liter}^{-1}$; yeast extract, $5 \mathrm{~g} \mathrm{liter}^{-1}$; dextrose, $\left.10 \mathrm{~g} \mathrm{liter}^{-1}\right)$ for $30 \mathrm{~h}$ at $25 \pm 1^{\circ} \mathrm{C}$ with shaking at $150 \mathrm{rpm}$. The medium was centrifuged (Avanti J-25; Beckman, Palo Alto, CA) at $8,315 \times g$ for $10 \mathrm{~min}$ and the cells were resuspended in $0.05 \mathrm{M}$ phosphate buffer ( $\mathrm{pH}$ 6.8). This was repeated twice, in order to wash the yeast cells from the nutritional compounds of the initial medium. The cells were resuspended in deionized water and the desired concentrations were obtained by adjusting the suspension cell concentration with a hemacytometer.

$P$. expansum and $B$. cinerea were isolated from decayed apples after several months in storage and were maintained on potato dextrose agar (PDA: extract from boiled potatoes, $200 \mathrm{ml}$; dextrose, $20 \mathrm{~g}$; agar, $20 \mathrm{~g}$; water, $800 \mathrm{ml}$ ). The conidial suspensions of 
$10^{4}$ conidia $\mathrm{ml}^{-1}$ were prepared from 10- and 14-day-old cultures of $P$. expansum and $B$. cinerea, respectively, and were determined with a hemacytometer.

Fruits and orchard. Blanquilla pears from commercial orchards in Lleida, Catalonia were used in all experiments on harvested fruit. Fruit were used following harvest or after storage at $1{ }^{\circ} \mathrm{C}$ (no longer than 3 months after harvest). In the field trials, the fruit trees were from a commercial orchard in Tornabous (Lleida, Catalonia, Spain).

Chemical products. The ammonium molybdate $\left(\left(\mathrm{NH}_{4}\right)_{6} \mathrm{Mo} 7 \mathrm{O}_{24}\right.$. $4 \mathrm{H}_{2} \mathrm{O}$ ) used in this study was purchased from Aldrich-Chemie (D7924 Steinheim, Germany), and cited as $\mathrm{NH}_{4}$-Mo.

Laboratory trials. For laboratory tests where the fruit were stored at $20^{\circ} \mathrm{C}$, pears were wounded $\left(3\right.$ by 3 by $3 \mathrm{~mm}^{3}$ ) at the stem (top) and calyx (bottom) end. Twenty-five microliters of each treatment was applied to the wounds, followed by inoculation with $20 \mu \mathrm{l}$ of an aqueous suspension of $P$. expansum or $B$. cinerea at $10^{4}$ conidia $\mathrm{ml}^{-1}$. Treatments consisted of (i) distilled water; (ii) C. sake at $2 \times 10^{6} \mathrm{CFU} \mathrm{ml}^{-1}$; (iii) C. sake at $2 \times 10^{7} \mathrm{CFU} \mathrm{ml}{ }^{-1}$; and (iv) aqueous solutions of $\mathrm{NH}_{4}$-Mo at $1,5,10$, or $15 \mathrm{mM}$ alone or in combination with $C$. sake at $2 \times 10^{6}$ or $2 \times 10^{7} \mathrm{CFU} \mathrm{ml}{ }^{-1}$. Lesion diameter was measured after 7 days of incubation at $20^{\circ} \mathrm{C}$ and $85 \pm 5 \%$ relative humidity $(\mathrm{RH})$. Each treatment was repeated three times with three fruit per replication. The test was repeated three times. The most effective treatments were selected for smallscale trials to control $P$. expansum and $B$. cinerea rot under cold storage conditions.

For laboratory tests where the fruit were stored at $1^{\circ} \mathrm{C}$, the fruit were treated as above, and the treatments consisted of (i) distilled water; (ii) C. sake at $2 \times 10^{6} \mathrm{CFU} \mathrm{ml}^{-1}$; (iii) $C$. sake at $2 \times$ $10^{7} \mathrm{CFU} \mathrm{m}{ }^{-1}$; and (iv) $\mathrm{NH}_{4}$-Mo at $5 \mathrm{mM}$ alone or in combination

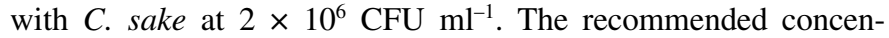
tration of $C$. sake (CPA-1) to control blue mold is $\approx 10^{7} \mathrm{CFU} \mathrm{m}{ }^{-1}$ (29); therefore, the concentration of $C$. sake at $2 \times 10^{7} \mathrm{CFU} \mathrm{m}{ }^{-1}$ was tested alone because the objective was to reduce the antagonist dose necessary to control decay. Ten fruit constituted a single replicate, and each treatment was replicated three times. The fruit were stored in a cold room at $1{ }^{\circ} \mathrm{C}$ and $90 \pm 5 \% \mathrm{RH}$ for 60 days. The test was repeated twice.

Semicommercial trials under cold storage conditions. To simulate commercial damage, a wound $(\approx 1 \mathrm{~mm}$ in diameter and $2 \mathrm{~mm}$ deep) was inflicted on each fruit at two locations (midway between the calyx and stem end) with a nail. The fruit were dipped in each treatment for $30 \mathrm{~s}$; fruit were left drying under ambient conditions and then were dipped again for $30 \mathrm{~s}$ in a conidial suspension of $P$. expansum or $B$. cinerea $\left(10^{4}\right.$ conidia $\left.\mathrm{ml}^{-1}\right)$. Treatments consisted of (i) distilled water; (ii) $C$. sake at $2 \times$ $10^{6} \mathrm{CFU} \mathrm{m}{ }^{-1}$; (iii) C. sake at $2 \times 10^{7} \mathrm{CFU} \mathrm{ml}^{-1}$; and (iv) $\mathrm{NH}_{4}-\mathrm{Mo}$ at $5 \mathrm{mM}$ alone or in combination with $C$. sake at $2 \times 10^{6} \mathrm{CFU} \mathrm{ml}^{-1}$. The fungicide imazalil (Decozil-S-7.5; Elf Atochem Agri España, Valencia, Spain) at the recommended rate for postharvest treatment $(0.5 \%)$ also was tested. Twenty fruit constituted a single replicate and each treatment was repeated four times. Lesion diameters were measured 5 months after cold storage at $1{ }^{\circ} \mathrm{C}$ and $21 \%$ $\mathrm{O}_{2}$ (ambient air). This study was conducted during two storage seasons (1997-98 and 1999-2000).

Blue mold suppression on pears stored at $1{ }^{\circ} \mathrm{C}$ and under low oxygen conditions $\left(2 \% \mathrm{O}_{2}-1 \% \mathrm{CO}_{2}\right)$ during 5 months also was

TABLE 1. Treatments used on the control of blue mold by preharvest treatments

\begin{tabular}{|c|c|c|c|c|c|c|}
\hline \multirow[b]{2}{*}{ Treatment $^{\mathrm{z}}$} & \multicolumn{2}{|c|}{ Preharvest treatment with $\mathrm{NH}_{4}$-Mo } & \multicolumn{2}{|r|}{ Postharvest } & \multicolumn{2}{|c|}{ Postharvest inoculation with } \\
\hline & 7 days before harvest & 2 days before harvest & Wounds & Treatment with $\mathrm{NH}_{4}$-Mo & Candida sake & Penicillium expansum \\
\hline Nontreated & - & - & + & - & - & + \\
\hline $\mathrm{NH}_{4}-\mathrm{MoPre} 7 \mathrm{~d}$ & + & - & + & - & - & + \\
\hline $\mathrm{NH}_{4}-\mathrm{MoPre} 7 \mathrm{~d}+\mathrm{CS}$ & + & - & + & - & + & + \\
\hline $\mathrm{NH}_{4}-\mathrm{MoPre} 2 \mathrm{~d}$ & - & + & + & - & - & + \\
\hline $\mathrm{NH}_{4}-\mathrm{MoPre} 7 \mathrm{~d}+\mathrm{CS}$ & - & + & + & - & + & + \\
\hline $\mathrm{NH}_{4}$-MoPost & - & - & + & + & - & + \\
\hline $\mathrm{NH}_{4}$-MoPost $+\mathrm{CS}$ & - & - & + & + & + & + \\
\hline $\mathrm{CS}$ & - & - & + & - & + & + \\
\hline
\end{tabular}

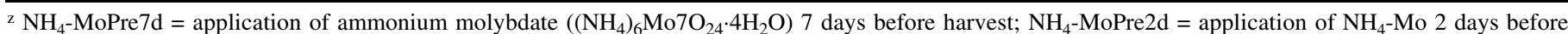
harvest; $\mathrm{CS}=$ Candida sake treatment; $\mathrm{NH}_{4}$-MoPost $=$ postharvest application of $\mathrm{NH}_{4}$-Mo.

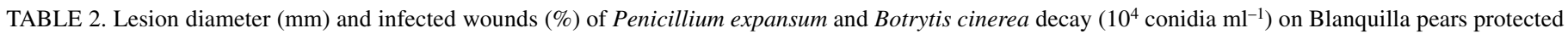
with Candida sake, ammonium molybdate $\left(\mathrm{NH}_{4}-\mathrm{Mo}\right)$, and their combination

\begin{tabular}{|c|c|c|c|c|c|}
\hline \multirow[b]{3}{*}{ C. sake $\left(\mathrm{CFU} \mathrm{ml} \mathrm{m}^{-1}\right)$} & \multirow[b]{3}{*}{$\mathrm{NH}_{4}$-Mo $(\mathrm{mM})$} & \multicolumn{4}{|c|}{ Pathogens ${ }^{\mathrm{z}}$} \\
\hline & & \multicolumn{2}{|c|}{ P. expansum } & \multicolumn{2}{|c|}{ B. cinerea } \\
\hline & & Lesion diameter (mm) & Infected wound (\%) & Lesion diameter $(\mathrm{mm})$ & Infected wound (\%) \\
\hline 0 & 0 & $34.0 \mathrm{a}$ & $100 \mathrm{a}$ & $42.7 \mathrm{a}$ & $100 \mathrm{a}$ \\
\hline 0 & 1 & $8.8 \mathrm{c}$ & $39 \mathrm{c}$ & $42.2 \mathrm{a}$ & $100 \mathrm{a}$ \\
\hline 0 & 5 & $8.2 \mathrm{c}$ & $33 \mathrm{c}$ & $29.7 \mathrm{~b}$ & $83 \mathrm{~b}$ \\
\hline 0 & 10 & $25.6 \mathrm{~b}$ & $89 \mathrm{~b}$ & $29.6 \mathrm{~b}$ & $100 \mathrm{a}$ \\
\hline 0 & 15 & $31.1 \mathrm{a}$ & $100 \mathrm{a}$ & $24.8 \mathrm{~b}$ & $67 \mathrm{c}$ \\
\hline $2 \times 10^{6}$ & 0 & $17.2 \mathrm{a}$ & $72 \mathrm{a}$ & $24.4 \mathrm{ab}$ & 89 a \\
\hline $2 \times 10^{6}$ & 1 & $1.2 \mathrm{~b}$ & $17 \mathrm{~b}$ & $27.8 \mathrm{a}$ & $78 \mathrm{ab}$ \\
\hline $2 \times 10^{6}$ & 5 & $0.0 \mathrm{~b}$ & $0 \mathrm{~b}$ & $15.6 \mathrm{~b}$ & $56 \mathrm{c}$ \\
\hline $2 \times 10^{6}$ & 10 & $20.9 \mathrm{a}$ & $89 a$ & $31.8 \mathrm{a}$ & $83 \mathrm{ab}$ \\
\hline $2 \times 10^{6}$ & 15 & $21.6 \mathrm{a}$ & $83 \mathrm{a}$ & $22.6 \mathrm{ab}$ & $72 \mathrm{~b}$ \\
\hline $2 \times 10^{7}$ & 0 & $10.4 \mathrm{a}$ & $56 \mathrm{a}$ & $10.2 \mathrm{a}$ & $50 \mathrm{a}$ \\
\hline $2 \times 10^{7}$ & 1 & $1.0 \mathrm{bc}$ & $6 \mathrm{c}$ & $15.2 \mathrm{a}$ & $56 \mathrm{a}$ \\
\hline $2 \times 10^{7}$ & 5 & $0.0 \mathrm{c}$ & $0 \mathrm{c}$ & $0.0 \mathrm{~b}$ & $0 \mathrm{~b}$ \\
\hline $2 \times 10^{7}$ & 10 & $6.7 \mathrm{ab}$ & $33 \mathrm{ab}$ & $1.3 \mathrm{~b}$ & $6 \mathrm{~b}$ \\
\hline $2 \times 10^{7}$ & 15 & $3.2 \mathrm{bc}$ & $17 \mathrm{bc}$ & $0.0 \mathrm{~b}$ & $0 \mathrm{~b}$ \\
\hline
\end{tabular}

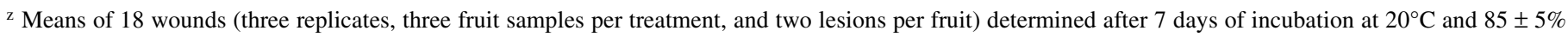
relative humidity. In relation to each concentration of the antagonist, different letters in the same column indicate significant difference between means using the least significant difference test. 
studied in the 1997-98 season with the methodology described above. The test was repeated twice.

Suppression of blue mold during cold storage by preharvest treatments. For fruit used for preharvest treatments, 20 trees were selected at random from an orchard of Blanquilla apple trees (8 years old at a spacing of 4 by $3 \mathrm{~m}$ ), growing at Lleida, Catalonia, Spain, with guard rows between sets of treatments. Each treatment was repeated four times and each replicate consisted of four trees (70 ripe pears). In all cases, a guard trees were used to separate randomized treatments and replicates. Eight treatments were studied to compare pre- and postharvest application of $\mathrm{NH}_{4}$-Mo in combination with postharvest application of $C$. sake to control blue mold on pears wounded at postharvest. The treatments used in this study are detailed in Table 1 and included the following combination of factors: preharvest application of $\mathrm{NH}_{4}$-Mo at $5 \mathrm{mM}$, postharvest wounding, postharvest application

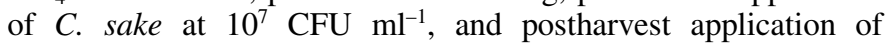
$\mathrm{NH}_{4}$-Mo at $5 \mathrm{mM}$ alone or in combination with $C$. sake at $10^{7} \mathrm{CFU} \mathrm{m}{ }^{-1}$.

Preharvest treatments were applied 7 and 2 days before harvest using a handgun operating at 10 atmospheres of pressure. After harvest, the fruit were placed in separate boxes according to treatment and replicate number, and each fruit was wounded as described previously. Postharvest treatments were applied by dipping the boxes containing fruit in a suspension of $\mathrm{NH}_{4}-\mathrm{Mo}, C$. sake, or $C$. sake plus $\mathrm{NH}_{4}$-Mo for $30 \mathrm{~s}$. All treatments included a final inoculation of the pathogen by dipping the boxes of fruits in a $10^{4}$ conidia $\mathrm{ml}^{-1}$ suspension of $P$. expansum for $30 \mathrm{~s}$. Once dried, the pears were stored at $1^{\circ} \mathrm{C}$ and $90 \pm 5 \% \mathrm{RH}$ in air. The number of infected wounds was determined after 4 months of storage. The test was repeated twice.

Effect of ammonium molybdate on $C$. sake (CPA-1) populations in pear wounds. On each pear, two wounds $(1 \mathrm{~mm}$ in diameter and $2 \mathrm{~mm}$ deep) were made in different locations midway between the calyx and the stem end. All fruit were dipped for $30 \mathrm{~s}$ into the antagonist suspension containing $2 \times 10^{6} \mathrm{CFU} \mathrm{ml}{ }^{-1}$ alone or in combination with 1 or $5 \mathrm{mM} \mathrm{NH}_{4}-\mathrm{Mo}$. Once dried, fruit were placed on tray packs in plastic boxes and incubated at $20^{\circ} \mathrm{C}$ and $85 \pm 5 \% \mathrm{RH}$ or at $1^{\circ} \mathrm{C}$ and $90 \pm 5 \% \mathrm{RH}$. Yeast populations were determined at 0 (just prior to storage), 24, 48, 72, and $168 \mathrm{~h}$ on fruit stored at $20^{\circ} \mathrm{C}$; and at $0,15,30,45$, and 60 days on fruit stored at $1{ }^{\circ} \mathrm{C}$.

Four pears constituted each replicate and 20 pieces of peel surface of $166 \mathrm{~cm}^{2}$ were removed (including the wounded areas) with a cork borer and a knife from each fruit. Peel surface pieces were shaken in $50 \mathrm{ml}$ of sterile $0.05 \mathrm{M}$ phosphate buffer $(\mathrm{pH}$ 6.5) on a rotary shaker for $20 \mathrm{~min}$ at $150 \mathrm{rpm}$ and then sonicated for $10 \mathrm{~min}$ in an ultrasound bath (Selecta, Abrera, Barcelona, Spain). This final step was used to improve detachment of the antagonist from the pear surface. Serial 10-fold dilutions of the washings were made with $0.05 \mathrm{M}$ phosphate buffer and plated on NYDA medium (the same as NYDB plus agar at $15 \mathrm{~g} \mathrm{liter}^{-1}$ ). Colonies were counted after incubation at $25^{\circ} \mathrm{C}$ in the dark for $48 \mathrm{~h}$. Population sizes were expressed as $\mathrm{CFU} \mathrm{\textrm {cm } ^ { - 2 }}$ of pear surface. Each treatment was repeated four times and the experiment was repeated twice.

Statistical treatment. Data of separate experiments were pooled when statistical analysis determined the absence of significant interactions between treatments and experiments. The effect of combining $\mathrm{NH}_{4}$-Mo with $C$. sake at room temperature was analyzed by two-way factorial analysis. Data of antagonist populations $\left(\mathrm{CFU} \mathrm{cm} \mathrm{cm}^{-2}\right)$ were transformed to logarithms to improve the homogeneity of variances. The incidence and severity of decay and yeast population dynamics were analyzed by an analysis of variance with SAS Software (version 6.08; SAS Institute, Cary, NC). Statistical significance was applied at the level $P<0.05$. When the analysis was statistically significant, the least significant difference test was applied to separate means.

\section{RESULTS}

Laboratory trials. From all $\mathrm{NH}_{4}$-Mo tested concentrations, the application of $5 \mathrm{mM}$ alone was the only one that significantly reduced the severity and incidence of both blue $(P=0.0001)$ and gray $(P=0.0012$ and $P=0.0001)$ molds (Table 2$)$. When combined with $C$. sake at $2 \times 10^{6}$ or $2 \times 10^{7} \mathrm{CFU} \mathrm{ml}{ }^{-1}, \mathrm{NH}_{4}$-Mo at 1 or $5 \mathrm{mM}$ markedly enhanced the efficacy of this biocontrol agent against blue mold decay. In addition, complete control of blue mold was achieved with the addition of $5 \mathrm{mM} \mathrm{NH}_{4}$-Mo to $C$.

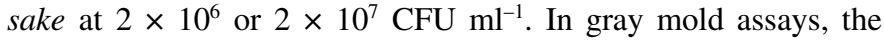
application of $\mathrm{NH}_{4}$-Mo alone at 5 or $15 \mathrm{mM}$ significantly reduced the severity $(P=0.0012)$ and incidence $(P=0.0001)$ of the decay. The combination of $C$. sake at $2 \times 10^{6} \mathrm{CFU} \mathrm{ml}^{-1}$ and $\mathrm{NH}_{4}-\mathrm{Mo}$ at $5 \mathrm{mM}$ enhanced the biocontrol agent activity on reducing incidence and severity of $B$. cinerea. Also, complete control was achieved with $C$. sake at $2 \times 10^{7} \mathrm{CFU} \mathrm{ml}{ }^{-1}$ plus $\mathrm{NH}_{4}$-Mo at 5 or $15 \mathrm{mM}$. The best and more consistent results were obtained with the addition of $\mathrm{NH}_{4}$-Mo at $5 \mathrm{mM}$ to $C$. sake; therefore, this concentration was selected for further experiments.

In laboratory trials under cold storage, all treatments significantly reduced the incidence $(P=0.0001)$ and severity $(P=0.0001)$ of blue and gray molds on pears stored at $1^{\circ} \mathrm{C}$ for 60 days (Fig. 1). The combined treatment (C. sake at $2 \times 10^{6} \mathrm{CFU} \mathrm{ml}^{-1}$ plus $\mathrm{NH}_{4}$ Mo at $5 \mathrm{mM}$ ) significantly enhanced the efficacy of this biocontrol agent against both pathogens. Complete control of blue mold was obtained in pears inoculated with the combination (Fig. 1A), and this performance was superior to the application of $C$. sake at $2 \times$ $10^{6}$ or $2 \times 10^{7} \mathrm{CFU} \mathrm{ml}^{-1}$ alone. The application of $\mathrm{NH}_{4}-\mathrm{Mo}$ alone reduced severity and incidence of blue mold by 91 and $86 \%$, respectively, compared with the control treatment. In the case of gray mold, the combined treatment enhanced the capacity of $C$. sake by $83 \%$ to reduce infected wounds (Fig. 1B). Similar control was obtained with the combination and $C$. sake at a higher concentration $\left(2 \times 10^{7} \mathrm{CFU} \mathrm{ml}^{-1}\right)$.

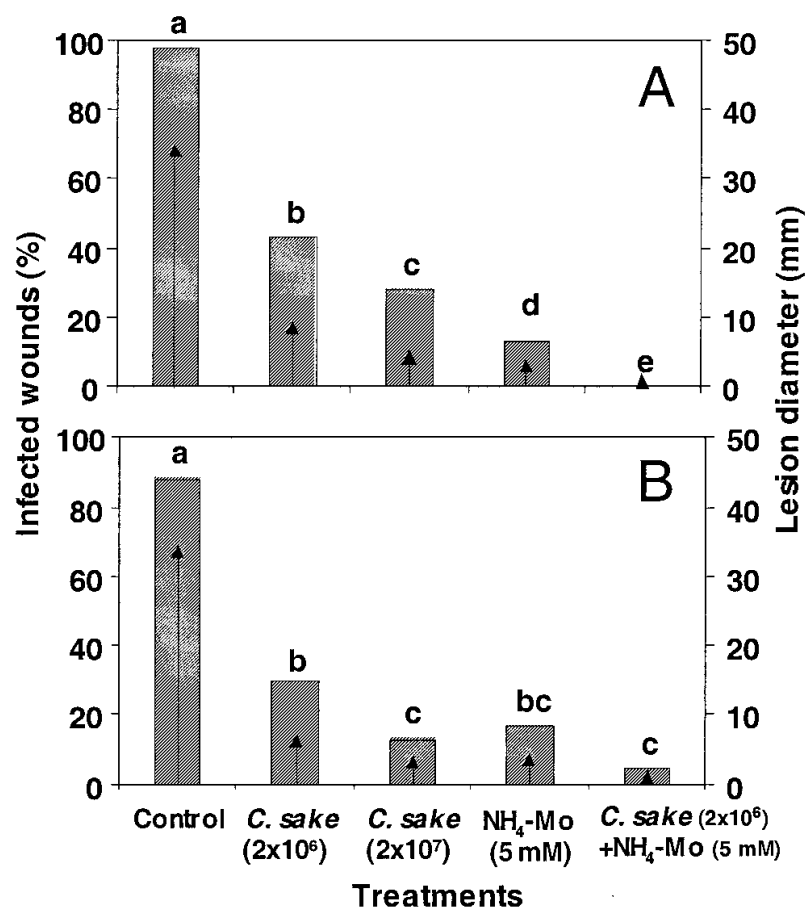

Fig. 1. Incidence ( $\boldsymbol{\square}$ ) and severity $(\mathbf{A})$ of $\mathbf{A}$, blue mold and $\mathbf{B}$, gray mold on wounded Blanquilla pears treated with Candida sake at $2 \times 10^{6}$ and $2 \times$ $10^{7} \mathrm{CFU} \mathrm{ml} \mathrm{m}^{-1}, \mathrm{NH}_{4}-\mathrm{Mo}$ at $5 \mathrm{mM}$, and the combination of $C$. sake at $2 \times$ $10^{6} \mathrm{CFU} \mathrm{mm^{-1 }}$ and $\mathrm{NH}_{4}-\mathrm{Mo}$ at $5 \mathrm{mM}$, followed by inoculation with the pathogens $\left(10^{4}\right.$ conidia $\left.\mathrm{ml}^{-1}\right)$ after 60 days of incubation at $1^{\circ} \mathrm{C}$ and $90 \pm 5 \%$ relative humidity. Within incidence, columns with the same letter are not significantly different according to the least significant difference test. 
Semicommercial trials under cold storage conditions. The effectiveness of the combined treatment was observed in semicommercial tests and also was compared with the postharvest fungicide imazalil (Figs. 2 and 3). The combined treatment significantly reduced incidence and severity of blue and gray molds under cold storage conditions in air (Fig. 2), as well as in reducing incidence and severity of blue mold during 5 months of storage under cold conditions in a low oxygen atmosphere (Fig. 3). In ambient air, all treatments significantly reduced blue mold in both seasons $(P=0.0001)$ (Fig. $2 \mathrm{~A})$. The efficacy of $C$. sake in reducing blue mold severity and incidence was enhanced by 92 and $88 \%$, respectively, with the addition of $\mathrm{NH}_{4}-\mathrm{Mo}$, in the 1999-2000 season. In both seasons, the efficacy of the combination was greater than $C$. sake at $2 \times 10^{7} \mathrm{CFU} \mathrm{ml}{ }^{-1}$ alone. Moreover decay among pears stored in the 1999-2000 season were not significantly different than that after application of $C$. sake plus $\mathrm{NH}_{4}-\mathrm{Mo}$ or imazalil. On pears treated with $\mathrm{NH}_{4}-\mathrm{Mo}$ at $5 \mathrm{mM}$ alone, the reduction of blue mold severity was greater than $91 \%$ in both seasons, and incidence was reduced by 73 and $87 \%$ in the $1997-98$ and 1999-2000 seasons, respectively.

In $B$. cinerea assays in cold storage in ambient air, the incidence and severity of gray mold in the 1997-98 season was very low after all treatments (Fig. 2B). In this season, no significant reduction in gray mold was observed after the application of $\mathrm{NH}_{4}$-Mo at $5 \mathrm{mM}$ or imazalil. Significantly similar but modest control was achieved with $C$. sake at both tested concentrations and the combined treatment. In the 1999-2000 season, all treatments significantly reduced gray mold $(P=0.0001)$, and similar control was achieved with the application of $\mathrm{NH}_{4}$-Mo alone or in combination with $C$. sake and imazalil (Fig. 2B). The combined treatment reduced the percentage of infected wounds from 50 to $6 \%$ and the mean lesion diameter from 58 to $4 \mathrm{~mm}$. The combined treatment enhanced $86 \%$ the efficacy of the $C$. sake on reducing incidence, and the reduction was superior to that observed with the application of $C$. sake at $2 \times 10^{7} \mathrm{CFU} \mathrm{ml}^{-1}$.
Under controlled atmosphere, all treatments significantly reduced blue mold $(P=0.0001)$ (Fig. 3). The combined treatment reduced blue mold by $86 \%$ and was not significantly different from the application of $\mathrm{NH}^{4}-\mathrm{Mo}$ alone or from the imazalil. The reduction in disease incidence achieved with the combination was $55 \%$ higher than that observed with $C$. sake at $2 \times 10^{6}$ or $2 \times$ $10^{7} \mathrm{CFU} \mathrm{ml}^{-1}$.

Suppression of blue mold during cold storage by preharvest applications. Preharvest application of $\mathrm{NH}_{4}$-Mo treatments alone did not reduce blue mold incidence (Fig. 4). On untreated pears and those treated with a preharvest application of $\mathrm{NH}_{4}-\mathrm{Mo}$, the incidence of blue mold was significantly higher (89\%) than on pears treated with $\mathrm{NH}_{4}$-Mo followed by postharvest $C$. sake application $(44 \%)$. No differences in incidence of blue mold were observed among preharvest applications of $\mathrm{NH}_{4}$-Mo followed by postharvest applications of $C$. sake, postharvest applications of $\mathrm{NH}_{4}-\mathrm{Mo}$, or postharvest applications of $C$. sake. The percentage of infected wounds in the postharvest treatment of $C$. sake plus $\mathrm{NH}_{4}$-Mo was significantly less than all treatments and was $90 \%$ less than the nontreated control.

Effect of ammonium molybdate on $C$. sake (CPA-1) populations in pear wounds. The growth rate of $C$. sake was reduced by $\mathrm{NH}_{4}-\mathrm{Mo}$ in pears stored at $20^{\circ} \mathrm{C}$ (Fig. 5A) and $1^{\circ} \mathrm{C}$ (Fig. 5B). At room temperature during the first $24 \mathrm{~h}, C$. sake populations increased 13-fold; whereas, in the presence of $\mathrm{NH}_{4}-\mathrm{Mo}$, the population increased only sevenfold (Fig. 5A). After this period, $C$. sake populations in presence of $\mathrm{NH}_{4}-\mathrm{Mo}$ at $5 \mathrm{mM}$ decreased. At the end of the experiment, the population was only fourfold higher than the initial population.

The effect of $\mathrm{NH}_{4}-\mathrm{Mo}$ on the growth of $C$. sake was greater on pears stored at $1{ }^{\circ} \mathrm{C}$ than at $20^{\circ} \mathrm{C}$. At this temperature, C. sake alone during the first 15 days increased 20 -fold and, at the end of the experiment, the population was 300 -fold higher than the initial population (Fig. 5B). Meanwhile, in the presence of $\mathrm{NH}_{4}-\mathrm{Mo}$ during the first 15 days, population of $C$. sake increased 10 -fold

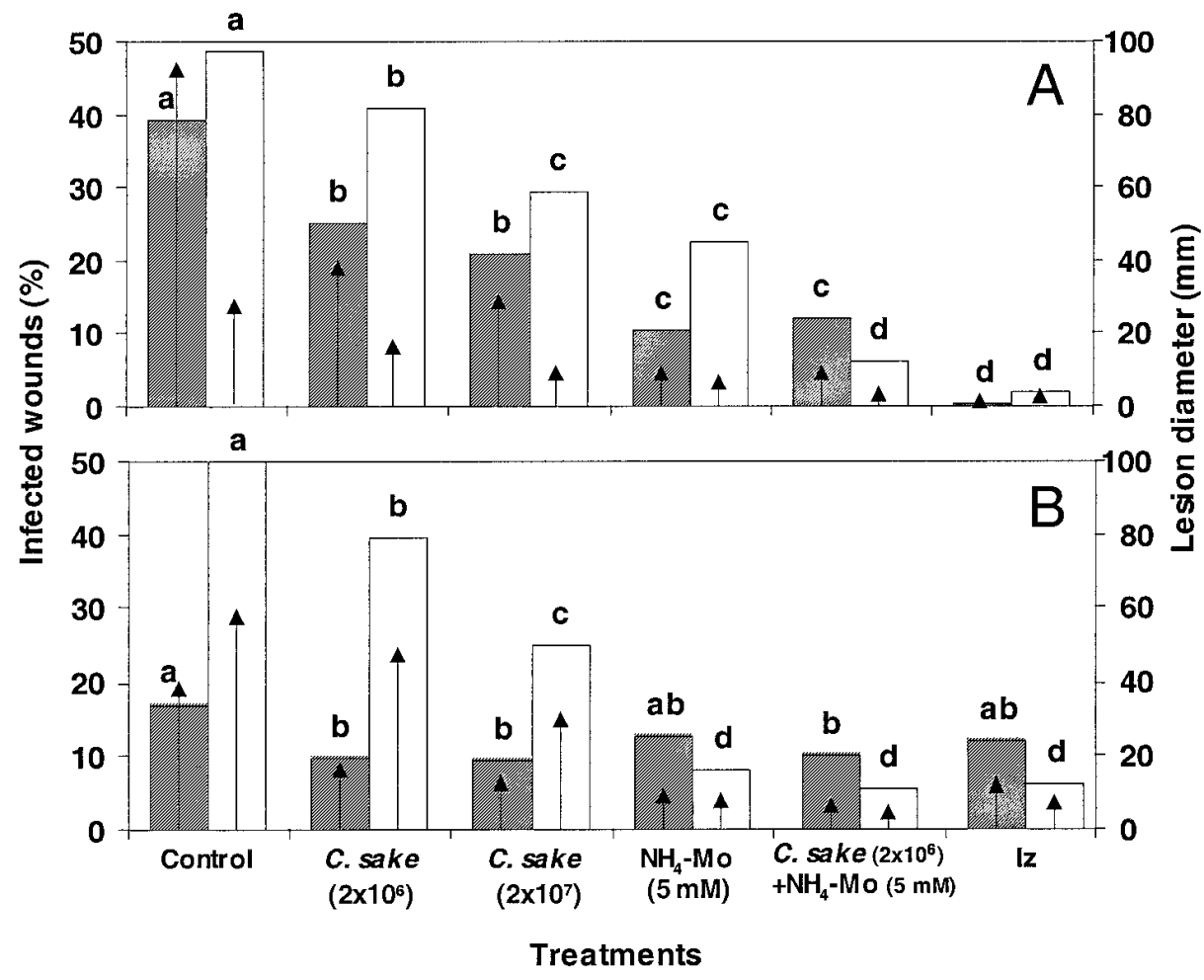

Fig. 2. Severity $(\mathbf{\Delta})$ and incidence of A, blue mold and B, gray mold during the 1997-98 season ( $\mathbf{\square})$ and the 1999-2000 ( $\square$ ) season on wounded Blanquilla

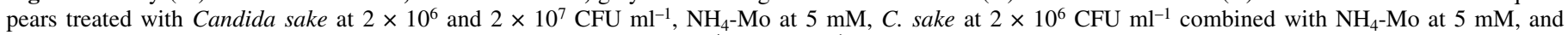
imazalil (0.5\%), followed by inoculation with Penicillium expansum $\left(10^{4}\right.$ conidia $\left.\mathrm{ml}^{-1}\right)$ after 5 months of incubation at $1^{\circ} \mathrm{C}$ in air. Within each season, letters are applied to incidence, and columns with the same letter are not significantly different according to the least significant difference test. 
and remained stable until the end of the experiment both at 1 and $5 \mathrm{mM}$ concentrations.

Under both storage conditions, increasing the concentration of $\mathrm{NH}_{4}$-Mo from 1 to $5 \mathrm{mM}$ in general did not affect the growth of C. sake.

\section{DISCUSSION}

Detailed studies have shown that $C$. sake CPA-1 is an effective antagonist of the major postharvest pathogens of pome fruit $(25$, $27,29)$ and has demonstrated a high degree of efficacy in controlling postharvest blue mold on apples in pilot tests (28). However, the capacity of $C$. sake to control postharvest diseases is greater on apples than on pears (26). In the present study, we demonstrated that $\mathrm{NH}_{4}$-Mo has great potential for controlling postharvest diseases on pears and could be used to enhance the antagonistic ability of $C$. sake (CPA-1) against the most important postharvest pathogens on pears. The efficacy trials at room temperature with $C$. sake plus $\mathrm{NH}_{4}$-Mo generally showed higher blue and gray mold control than applications of $C$. sake alone. Based

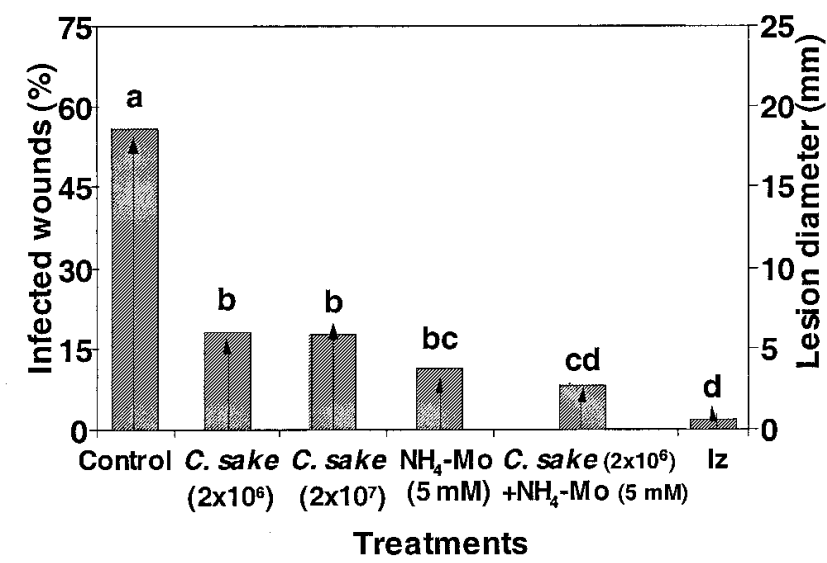

Fig. 3. Incidence ( $\boldsymbol{\square})$ and severity $(\boldsymbol{\Delta})$ of blue mold on wounded Blanquilla pears treated with Candida sake at $2 \times 10^{6}$ or $2 \times 10^{7} \mathrm{CFU} \mathrm{ml}{ }^{-1}, \mathrm{NH}_{4}-\mathrm{Mo}$ at $5 \mathrm{mM}, C$. sake at $2 \times 10^{6} \mathrm{CFU} \mathrm{ml}^{-1}$ combined with $\mathrm{NH}_{4}-\mathrm{Mo}$ at $5 \mathrm{mM}$, and imazalil $(0.5 \%)$, followed by inoculation with Penicillium expansum $\left(10^{4} \mathrm{co}-\right.$ nidia $\mathrm{ml}^{-1}$ ), after 5 months of incubation at $1^{\circ} \mathrm{C}$ with low oxygen atmosphere $\left(2 \% \mathrm{O}_{2}-1 \% \mathrm{CO}_{2}\right)$ during the $1997-98$ season. Within incidence, columns with the same letter are not significantly different according to the least significant difference test. on these results, $\mathrm{NH}_{4}$-Mo at $5 \mathrm{mM}$ was chosen to combine with $C$. sake at $2 \times 10^{6} \mathrm{CFU} \mathrm{ml}^{-1}$ to determine the efficacy of $\mathrm{NH}_{4}$-Mo on enhancing biocontrol activity of $C$. sake. Under cold storage during 60 days, the combined treatment usually offered better control of decay on pears artificially wounded than did $C$. sake at $2 \times 10^{7} \mathrm{CFU} \mathrm{m}{ }^{-1}$ alone or $\mathrm{NH}_{4}$-Mo at $5 \mathrm{mM}$ alone. In simulating commercial conditions under cold storage in air or a low oxygen atmosphere for 5 months, the consistency of laboratory trial results was maintained. The effectiveness of the combined treatment was usually comparable to that observed with the fungicide imazalil and in general provided a higher reduction in decay than the treatment of $C$. sake at $2 \times 10^{6}$ or $2 \times 10^{7} \mathrm{CFU} \mathrm{ml}^{-1}$ alone. The application of $\mathrm{NH}_{4}$-Mo alone also provided great control, and was usually comparable to $C$. sake at $2 \times 10^{7} \mathrm{CFU} \mathrm{ml}^{-1}$.

Enhancement of biocontrol activity has been reported with several additives. Janisiewicz et al. (13) reported the enhancement of Pseudomonas syringae biocontrol activity of blue mold on apples by the addition of nitrogenous compounds at room temperature. Wisniewski et al. (33) achieved the enhancement of $C$. oleophila at $10^{6} \mathrm{CFU} \mathrm{m} \mathrm{m}^{-1}$ by the addition of calcium salts. However, in that study, the concentration of calcium chloride needed to improved the efficacy of $C$. oleophila to control decay on apples was very high (90 and $180 \mathrm{mM}$ ). El-Ghaouth et al. (3) also reported that the combination of $C$. saitoana with $0.2 \%$ glycochitosan on semicommercial trials on apples stored at $18^{\circ} \mathrm{C}$ during 28 days enhanced the biocontrol activity of the antagonist. In that study, the concentration of the biocontrol agent was $10^{8} \mathrm{CFU} \mathrm{ml}{ }^{-1}$; they did not compare the effectiveness of the combination at a lower concentration of the antagonist.

Reliability and cost are two major factors that will determine the feasibility of any biocontrol system (13); thus, the concentration of the compounds needed to enhanced biocontrol activity as well as the concentration of the antagonist are very important. The biocontrol agent must be effective at concentrations reasonable for commercial development (8). From a practical point of view, the high limit of CFU ml ${ }^{-1}$ for many yeasts seems to be $\approx 5 \times$ $10^{7} \mathrm{CFU} \mathrm{ml} \mathrm{m}^{-1}$ (10) and the recommended concentration of $C$. sake conformed to this prerequisite by being generally effective at $10^{7} \mathrm{CFU} \mathrm{m} \mathrm{m}^{-1}$ (28). The results from the present study showed that the addition of $\mathrm{NH}_{4}$-Mo to $C$. sake allowed the antagonist concentration to be reduced at least to $2 \times 10^{6} \mathrm{CFU} \mathrm{ml}{ }^{-1}$ to confer a level disease control equivalent to a commercial recommended fungicide with the subsequent economic benefits, and facilitate industrial production of $C$. sake by reducing the total volumes that need to be produced.

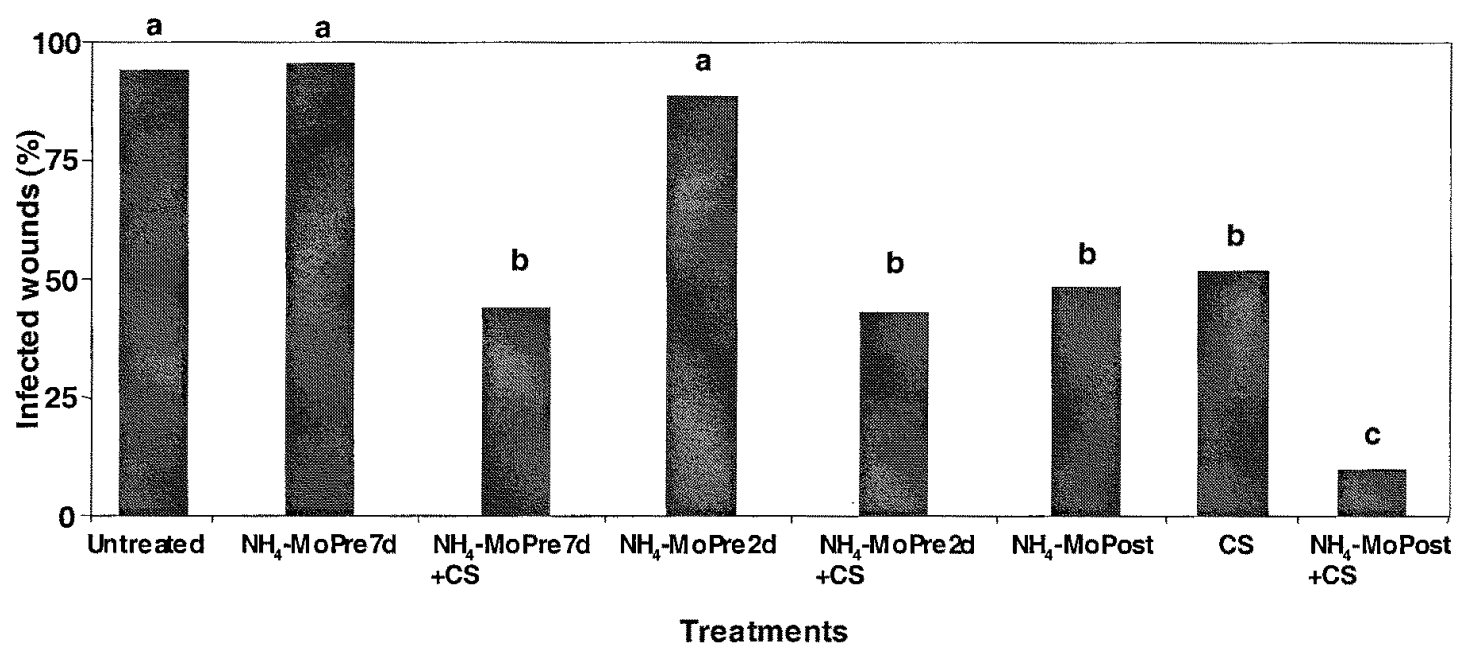

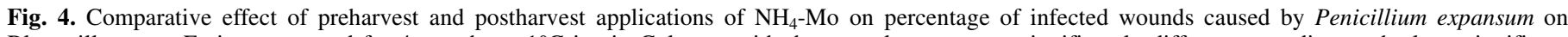

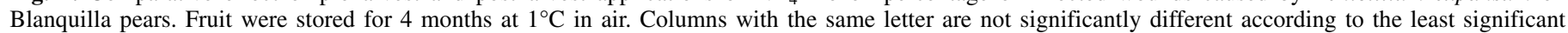
difference test. 
We did not find references reporting $\mathrm{NH}_{4}-\mathrm{Mo}$ as inhibitor of fungi growth apart from one study carried out on 1969 by Singh and Khanna (23). They observed that in vitro $\mathrm{NH}_{4}$-Mo inhibited mycelial growth of Alternaria tenuis but only at a concentration of or superior to $20 \mathrm{mM}$. When we tested $\mathrm{NH}_{4}-\mathrm{Mo}$ in vitro, we observed an inhibition of the spore germination of $P$. expansum and B. cinerea (C. Nunes, J. Usall, N. Teixidó, X. Ochoa de Eribe, and I. Viñas, unpublished data).

The ability of $C$. sake to colonize wounded fruit was affected in the presence of $\mathrm{NH}_{4}-\mathrm{Mo}$; however, the decrease in population did not seem to influence the control of decay. The observed increase in the $C$. sake population in the presence of $\mathrm{NH}_{4}$-Mo during the first 15 days at $1{ }^{\circ} \mathrm{C}$ could possibly restrict the nutrient availability to the pathogens, and made it possible to exploit both the antagonistic activity of $C$. sake and antifungal properties of $\mathrm{NH}_{4}-\mathrm{Mo}$. Some studies reported that one of the reasons for the biocontrol enhancement by additives is their effect on increasing antagonist population $(9,13,33)$. In this study, the effectiveness of the combination of $C$. sake with $\mathrm{NH}_{4}$-Mo may be due to the biological activity of $C$. sake and the antifungal property of $\mathrm{NH}_{4}-\mathrm{Mo}$. Ammonium molybdate is essential for growth of fungi (15); however, it seems that concentrations beyond the tolerance level of fungus disturbed its metabolic processes, resulting in its inhibition.

The preharvest application of $\mathrm{NH}_{4}$-Mo did not affect blue mold decay development; therefore, the reduction observed with treatments of preharvest application of $\mathrm{NH}_{4}$-Mo (at 7 and 2 days be-
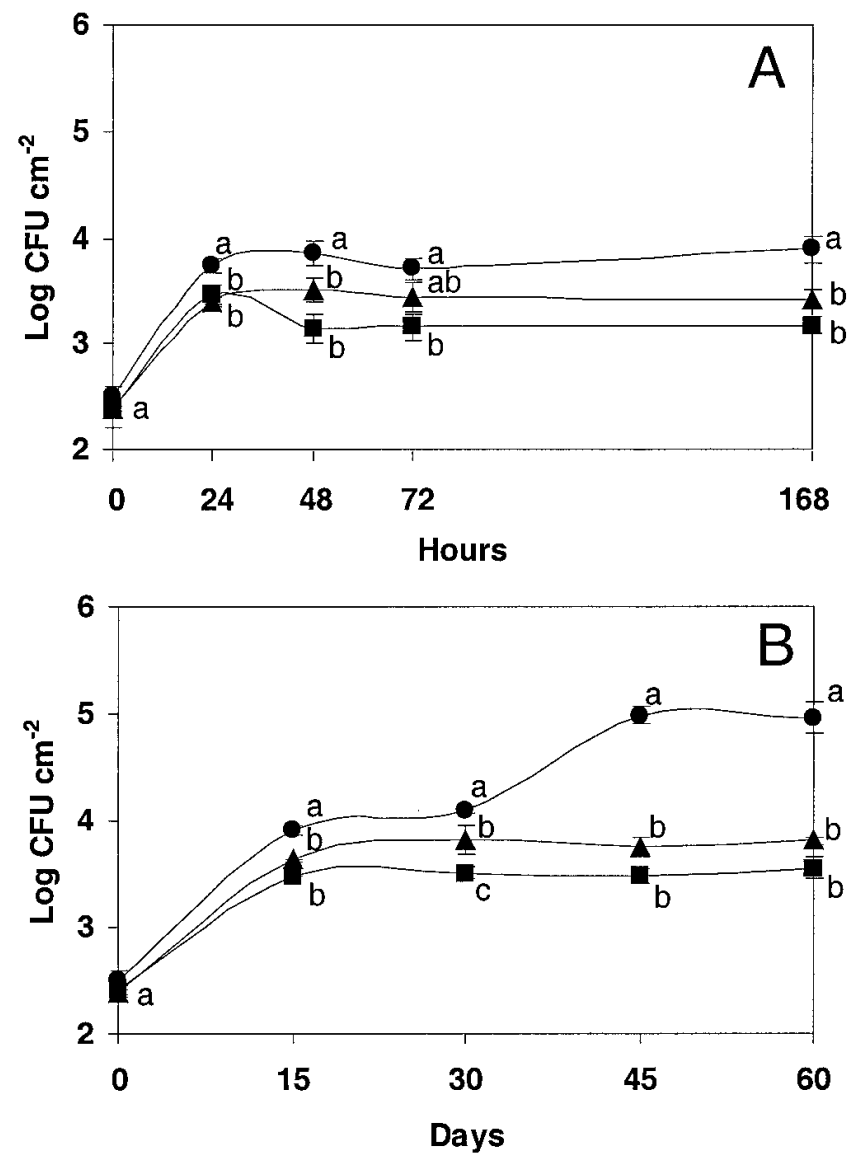

Fig. 5. Population dynamics of Candida sake on wounded pears treated with $20 \mu \mathrm{l}$ of: $C$. sake at $2 \times 10^{6} \mathrm{CFU} \mathrm{ml}^{-1}(\boldsymbol{)})$, or the combination of $C$. sake at $2 \times 10^{6} \mathrm{CFU} \mathrm{m}{ }^{-1}$ with $\mathrm{NH}_{4}$-Mo at $1 \mathrm{mM}(\boldsymbol{\Delta})$ or $5 \mathrm{mM}(\boldsymbol{\square})$, and incubated at $\mathbf{A}, 20^{\circ} \mathrm{C}$ and $85 \pm 5 \%$ relative humidity $(\mathrm{RH})$ and $\mathbf{B}, 1^{\circ} \mathrm{C}$ and $90 \pm 5 \% \mathrm{RH}$. Points represent the means of four replications and vertical bars indicate standard errors of the means. Within times, populations with the same letter are not significantly different according to the least significant difference test. fore harvest) followed by postharvest application of $C$. sake seems to be due to the effect of the antagonist. The preharvest application of $\mathrm{NH}_{4}-\mathrm{Mo}$ was made on unwounded pears and the fact that this treatment did not reduce blue mold decay is probably because a residue of $\mathrm{NH}_{4}$-Mo must remain on the wound to inhibit the infection. Smilanick et al. (24) found that the capacity of sodium carbonate or bicarbonate to control green mold on citrus was significantly reduced when the fruit were rinsed at high pressure. They concluded that this reduction occurred because the high pressure removes the residues of the compounds necessary to achieve control of green mold. Further research is needed in this area.

Toxicology date was determined by the Centre d'Investigació i Desenvolupament Aplicat (Barcelona, Catalonia, Spain), calculating the rat oral median lethal dose $\left(\mathrm{LD}_{50}\right)$. This work showed that the $\mathrm{LD}_{50}$ of ammonium molybdate is $1,714.3 \mathrm{mg} \mathrm{kg}^{-1}$ of live weight of Sprague Dawley rat and, at this concentration, no mortaity or alterations in tested animals were observed (data not shown).

In conclusion, our data indicated that manipulating the chemical environment by adding ammonium molybdate results in an improvement of $C$. sake antagonistic activity and provides a significant reduction in the amount of the yeast biomass required to achieve postharvest disease control of pears, with the consequent reduction of costs. The level of control conferred by dipping fruit in the combined treatment was superior or equivalent to imazalil, so we believe that $C$. sake could be applied with $\mathrm{NH}_{4}$ Mo as an additive by the traditional application method in packinghouses of dipping or drenching and facilitate their practical implementation.

\section{ACKNOWLEDGMENTS}

This work was supported by Subprograma Ciência e Tecnologia do $2^{\circ}$ Quadro Comunitário de Apoio from Portugal, by CICYT Comisión Interministerial de Ciencia y Tecnologia grant (ALI96-0567) from Spain, and by the Council of Lleida (La Paeria). We thank X. Ochoa de Eribe for his collaboration on field trials.

\section{LITERATURE CITED}

1. Blakeman, J. P., and Fokkema, N. J. 1982. Potential for biological control of plant diseases on phylloplane. Annu. Rev. Phytopathol. 20:167192.

2. Bodart, J. F., Béchard, D., Bertout, M., Rousseau, A., Gannon, J., Vilain, J. P., and Flament, S. 1999. Inhibition of protein tyrosine phosphatases blocks calcium-induced activation of metaphase II-arrested oocytes of Xenopus laevis. FEBS Lett. 457:175-178.

3. El-Ghaouth, A., Smilanick, J. L., Brown, G. E., Ippolito, A., Wisniewski, M., and Wilson, C. L. 2000. Application of Candida saitona and glycolchitosan for the control of postharvest diseases of apple and citrus fruit under semi-commercial conditions. Plant Dis. 84:243-248.

4. Filonow, A. B., Vishniac, H. S., Anderson, J. A., and Janisiewicz, W. J. 1996. Biological control of Botrytis cinerea in apple by yeasts from various habitats and their putative mechanisms of antagonism. Biol. Control 7:212-220.

5. Glew, R. H., Saha, A. K., Das, S., and Remaley, A. T. 1988. Biochemistry of the Leishmania species. Microbiol. Rev. 52:412-432.

6. Grangeasse, C., Doublet, P., Vincent, C., Vaganay, E., Riberty, M., Duclos, B., and Cozzone, A. J. 1998. Functional characterization of the low-molecular-mass phosphotyrosine-protein phosphatase of Actinetobacter johnsonii. J. Mol. Biol. 278:339-347.

7. Hunter, T. 1995. Protein kinases and phosphatases: The Yin and Yang of protein phosphorylation and signaling. Cell 80:225-236.

8. Janisiewicz, W. J. 1987. Postharvest biological control of blue-mould on apples. Phytopathology 77:481-485.

9. Janisiewicz, W. J. 1994. Enhancement of biological control of blue mold with the nutrient analog 2-deoxy-D-glucose on apples and pears. Appl. Environ. Microbiol. 60:2671-2676.

10. Janisiewicz, W. J. 1997. Biological control of postharvest diseases of temperate fruits. Pages 171-198 in: Plant-Microbe Interactions and Biological Control. G. J. Boland and L. D. Kuykendall, eds. Marcel Dekker, New York. 
11. Janisiewicz, W. J., Conway, W. S., Glen, D. M., and Sams, C. E. 1998. Integrating biological control and calcium treatment for controlling postharvest decay of apples. HortScience 33:105-109.

12. Janisiewicz, W. J., and Marchi, A. 1992. Control of storage rots on various pear cultivars with a saprophytic strain of Pseudomonas syringae. Plant Dis. 76:555-560.

13. Janisiewicz, W. J., Usall, J., and Bors, B. 1992. Nutritional enhancement of biological control of blue mold on apples. Phytopathology 82:13641370 .

14. Madrigal, C., Pascual, S., and Melgarejo, P. 1994. Biological control of peach twig blight (Monilinia laxa) with Epicoccum nigrum. Plant Pathol. 43:554-561.

15. Mathews, C. K., and Van Holle, K. E. 1996. Biochemistry. 2nd ed. Benjamin/Cummings, Menlo Park, CA.

16. McLaughlin, R. J., Wisniewski, M. E., Wilson, C. L., and Chalutz, E. 1990. Effect of inoculum concentration and salt solutions on biological control of postharvest diseases of apple with Candida sp. Phytopathology 80:456-461.

17. Morris, C. E., and Rouse, D. I. 1985. Role of nutrients in regulating epiphytic bacterial population. Pages 63-82 in: Biological Control on the Phylloplane. C. E. Windels and E. Lindow, eds. The American Phytopathological Society, St. Paul, MN.

18. Nunes, C., Usall, J., Teixidó, N., Miró, M., and Viñas, I. 2001. Nutritional enhancement of biocontrol activity of Candida sake (CPA-1) against Penicillium expansum on apples and pears. Eur. J. Plant Pathol. 107:543-551.

19. Nunes, C., Usall, J., Teixidó, N., and Viñas, I. 2001. Biological control of postharvest pear diseases using a bacterium Pantoea agglomerans CPA-2. Int. J. Food Microbiol. 70:53-61.

20. Pusey, P. L., and Wilson, C. L. 1984. Postharvest biological control stone fruit brown rot by Bacillus subtilis. Plant Dis. 68:753-756.

21. Remaley, A. T., Das, S., and Campbell, P. I. 1985. Characterization of Leishmania donovani acid phosphatases. J. Biol. Chem. 260:880-886.

22. Roberts, R. G. 1990. Postharvest biological control of gray mold of apple by Cryptococcus laurentii. Phytopathology 80:526-530.
23. Singh, R. S., and Khanna, R. N. 1969. Effect of certain inorganic chemicals on growth and spore germination of Alternaria tenuis Auct., the fungus causing core rot of mandarin oranges in India. Mycopathol. Mycol. Appl. 37:89-96.

24. Smilanick, J. L., Margosan, D. A., Mlikota, F., Usall, J., and Michael, I. F. 1999. Control of citrus green mold by carbonate and bicarbonate salts and the influence of commercial postharvest practices on their efficacy. Plant Dis. 83:139-145.

25. Teixidó, N., Viñas, I., Usall, J., and Magan, N. 1998. Control of blue mold of apples by preharvest application of Candida sake grown in media with different water activity. Phytopathology 88:960-964.

26. Usall, J. 1995. Control biològic de Penicillium expansum en postcollita de fruita de llavor. Ph.D. thesis. Universitat de Lleida, Lleida, Spain.

27. Usall, J., Teixidó, N., Fons, E., and Viñas, I. 2000. Biological control of blue mold on apple by a strain of Candida sake under several controlled atmosphere conditions. Int. J. Food Microbiol. 58:83-92.

28. Usall, J., Teixidó, N., Torres, R., Ochoa de Eribe, X., and Viñas, I. 2001. Pilots tests of Candida sake (CPA-1) applications to control postharvest blue mold on apple fruit. Postharvest Biol. Biotechnol. 21:147-156.

29. Viñas, I., Usall, J., Teixidó, N., and Sanchis, V. 1998. Biological control of major postharvest pathogens on apple with Candida sake. Int. J. Food Microbiol. 40:9-16.

30. Wang, G., Morré, D. J., and Shewfelt, R. L. 1995. Isolation of plasma membrane from Capsicum annum fruit tissue: Prevention of acid phosphatase contamination. Postharvest Biol. Biotechnol. 6:81-90.

31. Wilson, C. L., and Wisniewski, M. E. 1989. Biological control of postharvest diseases of fruits and vegetables: An emerging technology. Annu. Rev. Phytopathol. 27:425-441.

32. Wilson, C. L., Wisniewski, M. E., Droby, S., and Chalutz, E. 1993. A selection strategy for microbial antagonists to control postharvest diseases of fruits and vegetables. Sci. Hortic. (Amsterdam) 53:183-189.

33. Wisniewski, M. E., Droby, S., Chalutz, E., and Eilam, Y. 1995. Effects of $\mathrm{Ca}^{2+}$ and $\mathrm{Mg}^{2+}$ on Botrytis cinerea and Penicillium expansum in vitro and on the biological control activity of Candida oleophila. Plant Pathol. 44:1016-1024. 